\title{
Legal Protection for Creditors in Money Loans Agreement Lending with Constitutional Court's Decision No. 69 / PUU-XIII / 2015
}

\author{
Daniel Hendrawan ${ }^{1}$, Christian Andersen ${ }^{1} \&$ Theodora Novia Tjasa ${ }^{1}$ \\ ${ }^{1}$ Faculty of Law, Maranatha Christian University, Bandung, Indonesia \\ Correspondence: Daniel Hendrawan, Faculty of Law, Maranatha Christian University, Bandung, Indoensia. Tel: \\ 62-22-201-2186. E-mail: daniel.hendrawan@rocketmail.com
}

Received: July 11, 2019

doi:10.5539/jpl.v12n3p178
Accepted: July 29, $2019 \quad$ Online Published: August 30, 2019

URL: https://doi.org/10.5539/jpl.v12n3p178

\begin{abstract}
In Indonesia, the Marriage Agreement has long been valid and regulated in the legislation in Law Number 1 of 1974 concerning Marriage. Marriage Agreement regulates marriage property. In Article 29 paragraph (1) Law Number 1 Year 1974 concerning Marriage stipulates that marriage agreements must be made before the marriage takes place, but in 2015 the Constitutional Court issued Decision Number 69 / PUU-XIII / 2015 concerning changes to Article 29 paragraph (1), paragraph (3), and paragraph (4) of Law Number 1 of 1974 concerning Marriage which states that the Marriage Agreement can be made before, at the time of, and after the marriage takes place. The Constitutional Court ruling raises questions from various parties about how the legal consequences of the Marriage Agreement made after the marriage took place and what legal protection can be given to third parties on the Marriage Agreement which was made after the marriage took place.

This study uses a normative juridical research method that is descriptive analytical based on the merging of primary, secondary and tertiary data acquisition. The results of this study indicate that the legal consequences of the Marriage Agreement made after the marriage took place will have legal consequences for the parties themselves, assets, and also for third parties. Legal protection that can be given to creditors is to pay attention to the element of good faith in each loan agreement making so that creditors will be protected by themselves, if one of the parties making the loan agreement has bad faith, the loan agreement will automatically be canceled law because it does not meet the objective requirements.

The author's hope for this research is that the government can provide further regulation regarding the Constitutional Court Decision Number 69 / PUU-XIII / 2015 so that the public gets legal certainty in the implementation of the Decision and for the community the writer recommends restraint in carrying out the Decision until the regulation further from the government. Finally, the authors hope that this research can benefit the world of legal development in Indonesia.
\end{abstract}

Keywords: marriage, marriage agreement, lending and borrowing agreement, due to law, legal protection

\section{Introduction}

Article 1 Law Number 1 Year 1974 Regarding Marriage ("UUP") formulates that marriage is an inner and outer bond between a man and a woman to form a happy and eternal family based on the One Godhead. The article is very clear that marriage is not just a civil relationship, but marriage aims to form a family or family that is eternal and happy based on the One Godhead or based on Religious Law.(Neng Djubaidah, 2010, p. 3-4)

Marriage carried out by husband and wife legally will bring consequences in the public sector, one of which is the field of wealth, that the husband and wife are bound, both assets obtained from before the marriage or during marriage, this is regulated in Article 35 to Article 37 UUP. Property is one of the important elements in marriage. If you discuss the issue of property in marriage, then basically the assets acquired during marriage become one common asset. Article 119 of the Civil Code and Article 36 of the UUP provide an opportunity for the husband and wife partner if they decide to determine otherwise, in other words holding deviations from the provisions in the law. Deviations related to marital property can only be done by entering into a marriage agreement.

With the Constitutional Court Decision No. 69 / PUU-XIII / 2015 on Marriage Testament people who are not aware of any Marriage agreement can make the agreement despite the holding of the marriage. In accordance with the above case, the Constitutional Court Decision Number 69 / PUU-XIII / 2015 concerning the Marriage 
Agreement stipulates that the Marriage Agreement that is made may not harm a third party. However, the issue of the marriage agreement made by the husband and wife to the management and management of the property that occurs allows the arbitrary abuse of the assets of one party by the other party, in addition the Marriage Agreement applies to third parties so that the marriage agreement made after marriage Vulnerable cases occur when made carelessly without the accuracy and accuracy in making it and can harm third parties, one of which is creditors in the case of objects that are being guaranteed by the agreement of marriage after marriage. (agreement on marriage, 2017)

\subsection{Marriage Agreement}

In principle, the marriage agreement is the basis for the management of property in marriage . the arrangement of the marriage agreement should be put in place after the regulation of property in marriage, article 29 UUP does not explicitly stipulate that the marriage agreement is only limited to marital property. So that implicitly it can be interpreted that the marriage agreement is not limited to just regulating marriage assets.

The scope of the contents of the marriage agreement must not conflict with law, religion, and decency, at the same time it should not harm a third party if the agreement relates to marriage assets. In this case, Article 29 UUP states: (Wibowo T., Tunardy, 2012)

1) At the time before the marriage takes place, the two parties with mutual agreement can enter into a written agreement legalized by the Marriage Registration Officer, after which the contents also apply to third parties as long as the third party is involved;

2) The agreement cannot be legalized in violation of the boundaries of law, religion and morality;

3) The agreement takes effect from the time the marriage takes place;

4) During the marriage the agreement cannot be changed, except from both parties there is an agreement to change and the changes do not harm the third party.

\subsection{Lending and Borrowing Agreement}

Article 1754 of the Civil Code states:

"Borrowing and borrowing is an agreement by which one party gives to the other party with a certain amount of goods which is consumed by usage, provided that the latter party will return the same amount of the same type and quality."

In the case of borrowing money, the debts incurred therefore consist only of the amount of money mentioned in the agreement. According to Article 1756 of the Civil Code, if before repayment there is an increase or decline in price (value) or there is a change regarding the enactment of the currency, then the return on the amount borrowed must be made in the currency prevailing at that time. Thus, to determine the amount of money owed, we must start from the amount stated in the agreement.

In relation to determining the amount of money to be paid by the debtor in pre-World War II agreements, there is a well-known Supreme Court jurisprudence, which takes the basis for the revaluation of the outstanding amount: the price of prewar gold compared to the current price of gold, but the risk of the deterioration of the currency is borne by each party half. At first such decisions were made in determining the amount of ransom in the matter of land pawn, but then the debts of money also received the same treatment. The jurisprudence reflects an adoption of good faith which must be laid down in terms of the implementation of an agreement, as contained in article 1338 (3) of the Civil Code. (R. Subekti, 1995, p 127)

\subsection{End of Agreement}

Article 1381 of the Civil Code states ten ways to remove an agreement. These methods are:

a. Payment

b. Offer of cash payments followed by storage

c. Debt renewal

d. Compensation or calculation of reciprocal debt

e. Mixing debt

f. Debt relief

g. Destruction of goods intended in the agreement

h. Cancellation of agreement 


\section{Method}

\subsection{Types of Research}

The type of research used in this study is a normative juridical approach. Normative juridical research is legal research based on library references. Research with this method is focused on examining the application of rules or norms in positive law. In connection with this method, a logical assessment of the implementation of the marriage agreement is carried out after the enactment of the Constitutional Court Decision Number 69 / PUU-XIII / 2015 concerning the Marriage Agreement.

\subsection{Nature of Research}

The nature of the research used is descriptive analytical namely research that describes the events being studied and then analyzes them based on the facts in the form of secondary data obtained from primary legal material and secondary legal material. The purpose of descriptive research is to make a systematic, factual, and accurate explanation of the facts that occur in the field. In this study, the author will describe the situation and the Constitutional Court Decision Number 69 / PUU-XIII / 2015 concerning the Marriage Agreement with third parties.

\subsection{Research Approach}

The preparation of this study uses a statute approach and a conceptual approach. The law approach is to examine all laws and regulations relating to the topic of research. The conceptual approach moves from the views and doctrines that develop in legal science, will produce legal understanding, legal concepts, and relevant legal principles.

\subsection{Data Types}

The type of data used in this study is secondary data. Secondary data is data that is not taken directly from the resource person but through processing that is obtained from primary legal material, secondary legal material, and tertiary legal material. Material from secondary data, consisting of:

a. Primary Law Material.

Primary legal material is legal material consisting of laws and regulations that are sorted by hierarchy or positive legal material meaning a legal norm that has binding power. The rules used by the author include the Civil Code and the Constitutional Court Decision Number 69 / PUU-XIII / 2015 concerning Marriage Agreements.

\section{b. Secondary Legal Material}

Secondary legal materials are legal materials that complement primary legal materials such as draft laws, books written by legal experts, legal journals, seminar materials, doctrines of scholars, cases of law, jurisprudence, the results of the latest symposium relating with research topics, and other notes relating to the problem under study.

\section{c. Tertiary Legal Materials}

Tertiary legal materials are legal materials that provide guidance or explanation of primary legal materials and secondary legal materials, such as legal dictionaries, encyclopedia, and others.

\section{d. Data Collection Techniques}

Data collection techniques are obtained by means of library research from several literary sources such as books, internet, journals, or articles and other forms of work that are considered by the author to support the development of data on the implementation of marriage agreements after the Constitutional Court Decision Number 69 / PUU-XIII / 2015 concerning the Agreement Marriage.

e. Data Analysis Methods

The research data analysis method used is qualitative research with a mindset or deductive logic. According to Setyosari, deductive thinking is a process of thinking based on general statements to specific things using certain logic. If it is associated with legal research, the deductive mindset is a conclusion by relating the general premise (legislation, doctrine, principle, and principle) to a specific premise (real case or fact).

\section{Discussion}

\subsection{Legal Consequences of Marriage Agreements Made after the Marriage Is Held Based on the Constitutional} Court Decision Number 69 / PUU-XIII / 2015 concerning Marriage Agreements

The provisions of the Marriage Agreement after the Constitutional Court Decision Number 69 / PUU-XIII / 2015 stated that the Marriage Agreement can be made before, during, and during marriage. Based on the Decision, it was clear that the Decision had legal consequences and consequences for the community because the provisions of 
the Marriage Agreement stipulated in Article 29 of this UUP which had been in effect for approximately 40 years were later amended in 2015.

In the Decision there are changes made by the Constitutional Court to Article 29 paragraph (1), paragraph (3), and paragraph (4) UUP. The following changes can be seen in the table below:

Table 1. Comparison of article 29 UUP before and after decision of the constitutional court number 69 / PUU-XIII $/ 2015$

\begin{tabular}{lll}
\hline Article Before the verdict & Applicant's proposal Decision of the Constitutional Court \\
29 & & \\
UUP & & \\
\hline
\end{tabular}

(1) At the time before the At the time before the marriage At the time, before being held or as marriage takes place, the two takes place, the two parties long as in the marriage bond the two parties with mutual agreement with mutual agreement can parties for mutual agreement can can enter a written agreement enter a written agreement submit a written agreement ratified legalized by the Marriage legalized by the Marriage by the marriage registrar employee Recording Officer, after Recording Officer, after which or notary, after which the contents which the content applies to the content applies to third also apply to third parties as long as third parties as long as the parties as long as the third the third party is caught third party is involved. party is involved.

(3) The agreement came into The agreement came into The agreement takes effect from the effect since the marriage took effect since the marriage took time the marriage takes place, unless place. place. otherwise specified in the marriage agreement.

(4) During the marriage the During the marriage the During the marriage a marriage agreement cannot be changed, except if both parties have an agreement to change and the changes do not harm the third party. agreement cannot be changed, agreement can take place on marital except if both parties have an property or other agreements, agreement to change and the cannot be changed or revoked, changes do not harm the third except if both parties have an party. agreement to change or revoke and the change or revocation does not harm the third party.

In addition, the Constitutional Court Decision only arrived at that place, without providing legal certainty for the people who wished to make the Marriage Agreement, such as in terms of the provisions and arrangements for making a Marriage Agreement after the marriage took place, in the Notary's office. Until now, from several interviews that I read in journals and news, most Notaries in Indonesia have refrained from carrying out their names for making Marriage Marriage Agreement after marriage because according to the Notary itself there is no clarity from the government regarding the making of marriage agreements after the marriage took place, and according to the Notary also that the making of the Marriage Agreement could harm them if at any time the third party sued because the Marriage Agreement harmed the third party.

Therefore the author will explain the legal consequences of the Constitutional Court Decision No. 69 / PUU-XIII / 2015 towards the community as follows:

\subsubsection{Legal Consequences for the Parties That Make It}

In Article 1320 of the Civil Code, an agreement is valid if it fulfills 4 conditions, namely:

a. Agree that they are binding themselves; 
b. The ability to make an engagement;

c. A certain thing;

d. A reason that is lawful.

The four conditions also apply to the parties in a Marriage Agreement. the first and second conditions are said to be subjective conditions, while the third and fourth requirements are objective requirements. Marriage Agreement must fulfill Article 1320 of the Civil Code.

Based on the Decision of the Constitutional Court Article 29 paragraph (1) UUP reads:

"At the time, before being held or as long as in the marriage bond the two parties for mutual agreement can submit a written agreement that is ratified by the marriage registrar or notary, after which the content applies to third parties as long as the third party is caught".

From the Article it can be seen that the Marriage Agreement stipulated in the UUP requires the parties to make a Marriage Agreement in written form and with mutual agreement. Because the UUP requires the Marriage Agreement to be made in written form, the parties wishing to make a Marriage Agreement must make it in writing and not verbally. The Marriage Agreement is a written agreement and therefore, the Marriage Agreement can be used as a strong evidence in the Court.

Article 29 paragraph (4) UUP states that:

"As long as the marriage takes place, the marriage agreement can be related to marital property or other agreements, cannot be changed or revoked, unless from both parties there is an agreement to change or revoke and change or revocation does not harm a third party."

From the sound of the article it is clearly stated that the Marriage Agreement cannot be changed or revoked except with the agreement of both parties to amend or revoke the Marriage Agreement provided that it does not harm the third party. In the article, the principle of consensualism applies where an agreement must be reached or the agreement between parties will be made.

Marriage agreements that are made without authorization by the marriage registrar employee only apply to husband and wife. However, if the Marriage Agreement which has been made and ratified by the marriage registrar employee legally binds the husband and wife and the third party involved. This is also confirmed in Article 1338 of the Civil Code which states:

"All agreements made legally apply as laws for those who make them. The agreement is irrevocable other than with the agreement of both parties, or for reasons determined by law. Approval must be carried out in good faith."

The article says that all agreements made legally apply as laws for those who make them. That means that the Marriage Agreement that is legally made is also included in the agreement made legally and must be seen as an Act for husband and wife. If an agreement is seen as an Act, the agreement is binding on the parties where there are rights and obligations contained in the Marriage Agreement so that it must be carried out by the parties.

\subsubsection{Legal Effects on the Status of Marriage Assets}

Marriage assets which are joint assets are joint property rights or commonly referred to as eigendom cash . Joint property rights are divided into two types, namely joint property rights (gebon mede eigendom) and free joint property rights (vrije mede eigendom). In marriage, marriage property is included in the joint property rights that are bound, namely property rights arising from the presence of several people jointly being the owner of an object due to an already existing legal relationship between the owners. With the Marriage Agreement being made, the joint ownership rights of the parties are no longer valid. In making a Marriage Agreement after the marriage is carried out, the Notary usually requires a list of inventory of marital assets, which assets will be arranged which will later become the property of each party.

In making the Marriage Agreement does not rule out the possibility of the transfer of property but in civil law, not all objects can be easily transferred. Article 612 of the Civil Code:

"The surrender of movable goods, except for non-bodied objects, is carried out by actual surrender by or on behalf of the owner, or by the surrender of keys to the building where the goods are located. Submission is not required if the items that have to be submitted for reasons of other rights have been controlled by the person who should accept them."

Whereas according to Article 616 of the Civil Code: "the submission or appointment of immovable property is carried out with the announcement of the deed concerned in the manner specified in Article 620." Article 620 reads: 
"By heeding the provisions stated in the previous three articles, the announcement referred to above is carried out by transferring a complete authentic copy of the deed or decree of the Judge to the mortgage store in the area where the immovable property must be delivered, and with register this copy in the specified list. Together with that, the person concerned must also submit a second authentic copy or passage from the Judge's deed or decision, so that the mortgage keeper records in it the day of the transfer along with the part and number of the list concerned."

Therefore, according to the third article, submission or commonly referred to Levering moving objects with the delivery of immovable have different submission process. With regard to movable property, surrender can be done with real surrender (feitelijke levering) as well as juridical surrender (juridische levering). Meanwhile the submission of immovable objects must be made through the announcement of the relevant deed. In the event that the property is a land right, the transfer of rights will be regulated in Article 19 of the LoGA and its implementing regulations.

Article 29 paragraph (3) UUP according to Constitutional Court Decision No. 69 / PUU-XIII / 2015 d ikatakan that marriage Treaty entered into force since the marriage took place, unless otherwise provided in the Agreement. So that if the Marriage Agreement after the marriage takes place without determining its validity, then the legal consequences of the agreement will take effect since the marriage took place followed by the status of the joint assets to be separated if desired by the parties, without having to obtain a court decision regarding the separation of assets.

The parties making the Marriage Agreement must determine when the Marriage Agreement will come into force, because it has legal consequences for the status of the marriage property directly. Basically, each agreement is based on the principle of freedom of contract so that it can be legally justified regarding the contents of the Marriage Agreement including the entry into force of agreements made by both parties even without obtaining a court decision regarding the separation of assets as long as they are not contrary to Law, decency and order general.

\subsubsection{Legal Consequences for Third Parties}

In the Constitutional Court Decision Number 69 / PUU-XIII / 2015 Article 29 paragraph (1) states that the Marriage Agreement also applies to third parties as long as the third party is involved. According to Article 1340 of the Civil Code, the agreement generally only applies between the parties making the agreement without being able to cause loss or benefit to third parties. Unlike the agreement in general, the Marriage Agreement can apply to third parties. The application of the Marriage Agreement to third parties is regulated in Article 152 of the Civil Code which reads:

"The provisions contained in the Marriage Agreement, which are deviations and joint assets under the law, in whole or in part, will not apply to third parties, before the day of registration of the provisions in the public register, which must be held in the Registrar's Office at the District Court, which in the legal area the marriage is held, the court where the marriage certificate is registered, if the marriage takes place abroad. "

From these provisions it can be seen that a Marriage Agreement can be binding or valid for third parties after the Marriage Agreement is registered in the Registrar's Office of the District Court and issued by the District Court. Before the Marriage Agreement was registered, the parties had to face the Notary in the area where they had married. Marriage agreements that have not been registered in the Registrar's Office at the District Court are not binding on a third party but are valid for parties only. Similar to the Marriage Agreement made with a Notary deed and recorded in the registry office but not registered with the District Court, the Marriage Agreement only applies to husband and wife and not a third party. The third party referred to here is a creditor in a loan and loan agreement.

Given that the Marriage Agreement binds a third party the Marriage Agreement should be made before the marriage takes place. But with the Decision of the Constitutional Court Number 69 / PUU-XIII / 2015, Article 29 paragraph (1) states that the Agreement can be made before and during the marriage so that the third party position in the Marriage Agreement can be harmed and cause legal problems.

The third party in this case is the creditor can actually get two different consequences of the Marriage Agreement made after the marriage took place. The first result is that in this case the creditor's position will not be harmed by the marriage agreement made after the marriage is carried out if the third party can prove that what is used as collateral for the debt or that is promised as collateral in any form is obtained before the issuance of the District Court. In this case the creditor has strong evidence to be submitted before the Court. Meanwhile, the other consequence is that creditors cannot prove that what is used as collateral for debt or what is promised as collateral in any form is obtained before the issuance of the determination of the District Court. In such circumstances, the creditor will suffer losses in the case of the object being guaranteed by the couple because the collateral that used to be a joint asset is now their own property and the creditor cannot prove that the collateral was obtained before the 
issuance of the stipulation of the District Court.

\subsection{Legal Protection for Creditors in a Lending and Borrowing Agreement If the Debtor Makes a Marriage Agreement before the Lending and Borrowing Agreement Ends}

Referring to the theory of legal protection, legal protection exists in the form of preventive legal protection and also repressive legal protection. In a loan agreement if the debtor makes a marriage agreement before the loan agreement ends, it will have legal consequences for the creditor. If the result of making a Marriage Agreement is detrimental to the creditor, the protection of creditors is needed. Preventive legal protection against creditors is to adhere to the principle of good faith in lending and borrowing agreements carried out by creditors.

Some of the Marriage Agreements can cause harm to creditors if they are made in bad faith. So that creditors are not harmed, legal protection is needed for creditors. In a loan and loan agreement, usually in a loan agreement, a guarantee is needed so that if the debtor cannot return what is borrowed, then the guarantee can be directly owned by the creditor as compensation.

Article 1338 of the Civil Code says:

"All agreements made legally apply as laws for those who make them. The agreement is irrevocable other than with the agreement of both parties, or for reasons determined by law. Approval must be carried out in good faith "

In Article 1338 of the Civil Code it is said that every agreement made applies as an Act for those who make it. As well as approval must be carried out in good faith . Good faith is one of the most important parts of an agreement, meaning that both the creditor and the debtor must implement a loan agreement based on the trust or confidence and the goodwill of the parties. If in the loan agreement the absence of a good intention means that the agreement contains fraud planned by one of the parties, the agreement does not meet the legal requirements of the agreement. In other words, there is fraud in the loan lending agreement so that the agreement can be said null and void by law and immediately the agreement is immediately considered to have no binding legal force.

Article 1338 of the Civil Code is also contained in the principle of freedom of contract where each person is free to make an agreement in the form and contains anything but is also limited to Article 1320 of the Civil Code that any agreement made may not violate the Law, decency and public order. With the principle of freedom of contract, it means that the parties can determine a requirement or provisions in the agreement they make to protect the interests of the parties as long as they do not violate the Law, decency and public order. In the case of a loan lending agreement, usually the parties that make the loan agreement can negotiate in advance about what conditions or conditions will be stipulated in their loan agreement.

In the loan lending agreement, the creditor should include provisions or several conditions to protect himself other than the principle of good faith that the author discussed above. In addition, in making a loan and loan agreement, creditors must pay attention to the background section or commonly referred to as consideration or recital carefully where the contents of the recital are about the background of a situation in an agreement such as a statement that the loan agreement it is made when the debtor is still bound in marriage without making a marriage agreement.

\section{Result}

The marriage agreement made after the marriage takes place will have an impact on the parties who make it, the status of the marital property and the third party. Legal protection that can be given to creditors is to pay attention to and adhere to the principle of good faith in a loan and loan agreement made by both parties, namely between the debtor and creditor. Good faith is one of the important roles in an agreement so that if an agreement is not found in either party or both parties, then the agreement will be null and void . In addition, the creditor can list and state the position and condition of the debtor at that time bound in marriage with the absence of a Marriage Agreement in the background or recital so that if one day the debtor makes a Marriage Agreement, the creditor will not be harmed at all on the Agreement The marriage and the loan and loan agreement can be used as written evidence before the court.

\section{References}

Djubaidah, N. (2010). Marriage \& Marriage Recording Not Recorded According to Written Law in Indonesia and Islamic Law. Sinar Grafika, Jakarta.

Jurnalhukum.com. (2012). Property in Marriage. Retrieved May 5, 2018, from http://www.jurnalhukum.com/harta-benda-dalam-perkawinan/

Plus.google.com. (2017). Series: Marriage Agreement. Retrieved February 27, 2018, from https://plus.google.com/106959923825984306160/posts/GPyKVcPfilg 
Subekti, R. (1995). Aneka Agreement. Citra Aditya Bakti, Bandung.

\section{Copyrights}

Copyright for this article is retained by the author(s), with first publication rights granted to the journal.

This is an open-access article distributed under the terms and conditions of the Creative Commons Attribution license (http://creativecommons.org/licenses/by/4.0/). 